\title{
The Effect of Total Quality Management on Project Management
}

\author{
Dr. Abbas Umar Ibrahim ${ }^{1 *}$ Dr. Cross Ogohi Daniel ${ }^{2}$ \\ 1.Department of Business Administration, Nile University Of Nigeria, Plot 681, Cadastral Zone C-OO, Research \\ \& Institution Area, Jabi Airport Bypass, Abuja \\ 2.Departments of Public Administration/Banking and Finance, Nile University of Nigeria, Plot 681 Cadastral \\ Zone C-OO, Research \& Institutions Area, Jabi Airport Bypass, Abuja
}

\begin{abstract}
This study examined the relationship between total quality management practices on project management. Total quality management has now become an important aspect of management due to increased competition among companies and quality issues associated with company operations; the survival of a business mainly depends upon the quality associated with the product. The objectives of the study are; to establish the impact of TQM on project management; to determine the impact of TQM on organizational performance and sustainability. The total sample sizes of 100 respondents were used for the study. Chi-square was used to test the hypothesis. The findings revealed that there is significant impact of TQM on project management. In conclusions, the implementation of quality management systems has increased the profitability, enhanced sales, increased competitiveness and resulted in acquisition of bigger market share, enhanced service delivery. The following recommendations emanate from the study, there is need for the SON management to implement organizational culture change in the organization, Management commitment to quality need to convey the posture, philosophy and actions that total quality management implementation will receive a higher priority in the organization.
\end{abstract}

Keywords: Total Quality Management, Project Management

DOI: $10.7176 / \mathrm{EJBM} / 11-17-10$

Publication date:June $30^{\text {th }} 2019$

\section{Introduction}

Total quality management has now become an important aspect of management due to increased competition among companies and quality issues associated with company operations; the survival of a business mainly depends upon the quality associated with the product. However, competition has become more challenging today than ever before, while customer expectations of service quality are higher than ever. To deliver superior quality of service to the customers, organizations are re-engineering their systems, operations, culture and adopting strategies in order to be customer focused. Quality has emerged to be the key component and critical success factor in most manufacturing as well as service organizations.

The dynamic nature of changes in the environment, particularly as they affect the tastes and aspirations of consumers, underscores the need to respond effectively to challenges posed by the changes. On the account of deregulation of Nigeria economy, competition has become a major challenge which chief executives must meet effectively in order to remain in business. Most managers agree that if an organisation is to be successful, it must change continually in response to significant development, such as customer needs, technological breakthroughs and government regulations (Eke, 2011). Globalization of market and operations forces organisations to think over their quality problems and in turn their overall organisational competitiveness. In order to be successful in this global market, organisations should dedicate themselves to improving productivity and quality in a timely and collaborative manner (Dobyns and Crawford, 2014). Almaraz (1994) also indicates that productivity and quality are integral components of organizational strategies. Designing and developing suitable strategies, techniques, tools and models for improving productivity and quality have become an essential function of researchers and practitioners in a networked global economy.

In recent times, the concept of customer services has risen to the centre stage of modern business. As a result of this development, the management vocabulary is now replete with all kinds of technologies which are used to describe one and the same thing, customer service. Among these terminologies are customer satisfaction, customer care, customer relations, etc. (Nwosu, 2016).

To achieve world class customer service, Total Quality Management (TQM) techniques, supported by management commitment and good organization will provide objective means of improving quality and hence the overall organizational competitiveness (Christopher, 2014).

Total quality management is among the new techniques which modern organizations now employ with very good result to secure and keep their customers permanently satisfied. It is therefore a way of managing to improve the effectiveness, efficiency, flexibility and competitiveness of a business as a whole (Christopher, 2014).

Benon and Savaph (2011) assert that TQM involves the whole organisations, getting organized in every department, in every activity with every single person at every level. This involves putting in place, process and system which will ensure that every aspect of its activity is aligned to satisfying customer needs and the 
organisation's objectives. Thus for an organisations to be fully effective, every single part of it must work properly together because every person and every activity affect and in turn is affected by others.

Dobyns and Crawford (2014) expatiate further that TQM involves deep understanding of three basic components, namely; the system, the process and the philosophy from which the organisations is extracted. The process here approximates to the necessary economic transformation from an underdeveloped economy to a modern industrial state. It also involves the uplifting of the basic quality of life of its people through modern processes of production. It involves still, the harnessing of the human and material resources for the goal of fitting into the system above.

The third component of TQM, the philosophy involves the identification of goals which have been partially addressed under the process as well as the means of attaining the goals.

Thus, TQM involves any attempt to improve quality at every phase of an organization's work whether it is on corporate plan initiation, implementation, personnel selection or customer satisfaction. Therefore, the ability to meet customer requirement is vital not only between two separate organisations but also within the same organisations. Ryan (2018) argues that quality has to be managed, it will not just happen. Clearly it must involve everyone in the process and be applied throughout an organisations. Failure to meet the requirements in any part of the quality chains has a way of multiplying, as failure in one part of the system creates problems elsewhere leading to a cycle of yet more failures and more problems. The price of quality is the continued examination of the requirements and the ability to meet them. This will lead to a continuous improvement.

\subsection{Statement of Problem}

Evidence abounds that poor quality culture has been the blight of management in Nigeria. This record contrasts sharply with empirical evidence from developed nations, where remarkable development has been recorded in almost all fields of human endeavour. Final delivery is still judged to fall below expectation in Nigeria and lack of consistence has been given as the main reason for the suboptimal performance of many organizations. Many government agencies are said to believe in compromising supervision for their personal gain.

A number of studies have been undertaken in total quality management in organizations. In their study Hassan, Mukhtar, Qureshi and Sharif (2012) examined the association between quality management practices and performance in Pakistan's manufacturing industry. The study established that quality management systems practices positively impact the performance. Irfan, Ijaz, Kee and Awan (2012) in their findings on improving operational performance of public hospital in Pakistan, established that selected Quality management systems practices have a significant positive impact on operational performance.

Dawn, (2011) investigated the application of TQM and found out that despite the fact that quality management has been addressed within a firm, Total Quality Management and its underlying assumptions could also be applicable to strategy management. However the study shows application of TQM in a telecommunication set up and concluded that TQM is very critical to organization efficiency. Gayah, (2012) in his study tries to show how human resource planning practices are affected by TQM and what needs to be improved for implementing TQM in any firm, but his study did not focus on operational performance. In Harari (1997) empirical study of the influence of quality systems, he concludes that only about one in three quality management systems programs in public and corporate institutions achieve significant improvements in quality and performance. Thus, this study seeks to fill this gap by establishing the relationship between total quality management practices and project management in public owned agency

\subsection{Objectives of the Study}

The broad objective of the study was to investigate the impact of Total Quality Management on project management. The specific objectives of the study are as follows;

i. To determine the impact of TQM on organizational performance and sustainability

\subsection{Research Hypothesis}

The hypothesis of the study was presented in null form at five percent critical leve

$\mathrm{H}_{0}$ : There is no significant impact pattern of TQM on organizational performance and sustainability.

\section{Literature Review}

\subsection{Conceptual Framework}

The International Standard ISO 8402, Quality Management and Quality Assurance Terminology defined Total Quality Managements the management approach of an organization, centered on quality, based on the participation of all its members and aiming at long-term success through customer satisfaction, and benefits to all members of the organization and to society (Ljungstrom and Klefsjo, 2002). Temtime and Solomon (2002) stated that Total Quality Management seeks continuous improvement in the quality of all processes, people, products, and services of an organization. Total Quality Management is also a systems approach to management that aims to enhance 
value to customers by designing and continually improving organizational processes and systems (Kartha, 2004). The emphasis is on employee involvement and empowerment along with customers and customer satisfaction as the focal point. The tenets of Total Quality Management are continuous improvement, top management leadership commitment to the goal of customer satisfaction, employee empowerment, and customer focus (Ugboro and Obeng, 2000). Total Quality Management means that the organization's culture is defined by and supports the constant attainment of customer satisfaction through an integrated system of tools, techniques and training, (Sashkin and Kiser, 1993). Even though many thinks that Total Quality Management is old, many of the new continuous improvement initiatives are based on Total Quality Management philosophies. Total Quality Management encompasses a number of different initiatives. For example, Six Sigma, which is popular today, is a methodology within Total Quality Management, not an alternative to it (Klefsjo, et al, 2001). Lean Sigma is another methodology that is widely used today that is included within Total Quality Management. Total Quality Management also includes initiatives such as ISO 9000 and the Malcolm Baldrige National Quality Award (MBNQA). Regardless of the different perspectives, the underlying theme common to all frameworks is that Total Quality Management is based on a prevention work process that strives to increase quality and efficiency, improve productivity, and enhance customer satisfaction, (Waldman and Addae, 1993; Kartha, 2004; Goldman, 2005). The main values that are essential in implementing a Total Quality Management process include the following elements: (1) quality information must be used for improvement, not to judge or control people; (2) authority must be equal to responsibility;(3) there must be rewards for results; (4) cooperation, not competition, must be the basis for working together; (5) employees must have secure jobs; (6) there must be a climate of fairness; (7) compensation should be equitable; and (8) employees should have an ownership stake.

Adeoti (2003) examined the gains of application of total quality management in the service industry with particular reference to the commercial banks in Nigeria and also to see how the application of TQM can prevent future threats of distress in commercial banks. Three banks were selected randomly, one to represent each of the three generation banks. The results of the study showed that the quality and quantity of employees employed determine to a very large extent the survival of any bank, also that the application of TQM is not immunity against distress but a preventive mechanism for distress.

\subsection{Theoretical Framework}

The theory of quality management has been developed from three different areas:

First, contributions from quality leaders (Deming, 1986; Ishikawa, 1985; Juran, 1992), Second, formal quality award models (Malcolm Baldrige National Quality Award-MBNQA; European Quality Award - EQA; The Deming Prize; Kanji Business Excellence Model) and third, measurement studies (Rahman, 2001; Sila, 2005; Prajogo, 2005; Brah and Lim, 2006;; Ya'acob, 2008; Salaheldin, 2009; Satish \& Srinivasan, 2010; Arumugam \& Mojtahedzadeh, 2011).

This theory of quality management has recognized many quality management systems practices such as quality management systems practices which have been documented and empirically analyzed in measurement studies and in studies that have investigated the relationship between quality management systems practices and performance. Saraph, Benson and Schroeder (1989) proposed Seventy eight items that were grouped in to eight critical quality management systems practices: role of divisional top management and quality policy, process management, product and service design, training, quality data and reporting, supplier quality management, role of the quality department and 8)employee relations. To measure quality management, Lu and Sohal (1993) used nine quality management systems practices: Top management commitment, Strategic quality management, Process quality management, Design quality management, Education and Training, Information and Analysis, Benchmarking, Resources and Statistical process control.

\section{Methodological Approach}

The research an empirical study which investigates the impact of TQM approaches on project management. The data used were collected through questionnaire based on Five-point Likert Scale analysed based on formulated hypotheses.

\subsection{Test of Hypothesis}

$\mathrm{H}_{0}$ : There is no significant impact of TQM on organizational project management 


Table for Chi-square Hypothesis
\begin{tabular}{|l|l|l|l|l|l|}
\hline RESPONSES & FO & FE & FO-FE & (FO-FE)2 & (FO-FE)2/FE \\
\hline Yes & 94 & 48 & 46 & 2116 & 44.08 \\
\hline No & 2 & 48 & -46 & 2116 & 44.08 \\
\hline Total & 96 & 96 & & & 88.08 \\
\hline & & & & $X^{2}$ & 88.08 \\
\hline
\end{tabular}

Source: Author's computation

$\mathrm{X}^{2}=\Sigma(\mathrm{FO}-\mathrm{FE})^{2} / \mathrm{FE}=88.08$

Now, the critical $X^{2}$ from the degree of freedom $1(K-1)=1$, hence the critical $X^{2}=2.706$.

Decision Rule

Accept $\mathrm{H} 0$ if $\mathrm{X}^{2}$ critical is greater than $\mathrm{X}^{2}$ calculated, otherwise reject H0and accept Hi (The alternative hypothesis).

Decision: Since $\mathrm{X}^{2}$ calculated, 88.08 is greater than $\mathrm{X}^{2}$ critical (from table), we reject $\mathrm{H}_{0}$ and accept $\mathrm{H}_{\mathrm{i}}$, that $\mathrm{H}_{0} 2$ : that there is significant impact pattern of TQM on organizational project management.

\section{Discussion of findings}

In the Chi-square result showed that the pattern of TQM is vital to the organizational performance and sustainability. The results indicated that there is a strong association between TQM and project management at SON. Therefore, Hi is accepted, meaning there is there is significant impact of TQM organizational project management. However, this result is in tandem with findings of Adeoti (2003)

\section{Conclusion}

Implementation of total quality management facilitate leadership to provide the necessary resources to meet the new requirements resulting from quality management systems, provided conductive working environment to employee involvement in quality management process. It also influenced the decision of selecting qualified suppliers and certifying suppliers for quality material, creates strategies, plans and systems for achieving superior quality in the institution and that has inspired staff and management in effective and efficient use of the resources and efforts of the institution towards quality excellence. The implementation of total quality management ensures that every worker in the organization does his work with quality the first time, thus improving the efficiency of operation and avoiding some cost associated with waste and rework.

\section{Recommendations}

There is need for SON management to implement organizational culture change in the organization so as to enhance the implementation of total quality management so as to enhance the organization's strategy of continuous improvement, open communication and cooperation throughout the organization.

In addition, there is need for management commitment to quality need to convey the posture, philosophy and actions that total quality management implementation will receive a higher priority in the organization.

There is need prioritize and enhance total quality management training process to help in preparing employees towards managing the total quality management, so as to be able to identify and contribute to ongoing quality improvement process of operational efficiency.

\section{REFERENCES}

Aghazadeh, S. (2002), "Implementation of total quality management in the managed care industry", The Total Quality Management Magazine, Vol. 14 No. 2, pp. 79-91.

Agus, A. (1994). Total Quality Managements a focus for improving overall service performance and customer satisfaction: an Empirical study on a Public Service sector in Malaysia, Total Quality Management, 15(5-6), 615-628.

Agus, A. (2004), "Total Quality Managements a focus for improving overall service performance and customer satisfaction: an empirical study on a public service sector in Malaysia", Total Quality Management and Business Excellence, Vol. 15 No. 5, pp. 615-28.

Agwu M. E., Ikpefan, O. A., Atuma O. \& Achugamonu, B. U. (2014) Conceptual Review of the Effects of Advertising on Consumer Buying Behaviour; International Review of Social Sciences, Vol. 2 Issue.11, pp. 502-518, November, 2014. Available at www.irss.academyirmbr.com

Agwu, E. M. (2014). An investigative analysis of factors influencing E-business adoption and maintenance of commercial websites in Nigeria; Basic Research Journal of Business Management and Accounts ISSN 23156899 Vol. 3(1) pp. 05-16 January 2014 - Available online at: http//www.basicresearchjournals.org

Aksu, M. B. (2003). Total Quality Management Readiness Level Perceived by the administrators working for the central organization of the ministry of National Education in Turkey, Total Quality Management and Business Excellence, 14(5), July, 595-608. 
Al-Marri, K., Ahmed, A. M. M. B, \& Zairi, M. (2007). Excellence in service: an empirical study of the UAE banking sector, International Journal of Quality \& Reliability Management, 24(2), 164-176.

Anderson, E. W., Fornell, C., \& Lehmann, D. R. (1994). Customer satisfaction, market share and profitability: findings from Sweden. Journal of Marketing, 58, 53-66.

Devarag, S., (1995), "A part analytic model of a theory of quality management underlying the Deming management method," preliminary and empirical finding, Decision Science 26, pp. 341-359.

Dimitriades, A. S. (2006). Customer satisfaction, loyalty and commitment in service organizations: some evidence from Greece, Management Research News, 29(12), 782-800.

Dow, D., Samson, D., \& Ford, S. (1999). Exploding the myth: Do all quality management practices contribute to superior quality performance? Production and Operations Management, 8, 1-28.

Dudu, O.F. and Agwu, M. E. (2014) A review of the effect of pricing strategies on the purchase of consumer goods, International Journal of Research in Management, Science \& Technology (E-ISSN: 2321-3264) Vol. 2, No. 2, pp.88-102, August 2014 Available at www.ijrmst.org

Eklof, J.A. and Westlund, A. (1988), "Customer satisfaction index and its role in quality management", The TQM Magazine Vol. 8 No. 1, pp.1-27.

Elango, R. \& Gudep, V. K., (2006). A Comparative Study on the Service Quality and Customers Satisfaction among Private, Public and Foreign banks. The ICFAI Journal of Management, 5 (3), 8-19

Elmuti, D.S. and Kathawala, Y. (1999),"Small service firms face implementation challenges", Quality Progress, Vol. 32 No. 4, pp. 67-65.

Engel, S. \& Kapp, K. (2004). Sovereign bank develops a methodology for predicting the ROI of Training Program, Journal of Organizational Excellence, 23 (spring), 51- 60.

Feigenbaum, A.V. (1983), Total Quality Control, McGraw-Hill, New York, NY, pp.112.

Forza, C., Flippiny, R., (1998), "Total Quality Management impact on quality performance and customer satisfaction: a conceptual model," International Journal of Production Economic 55, pp. 1-20.

Gberevbie, D. E. I. and M. Isiavwe-Ogbari (2007) "Creating Enabling Environments for Small and Medium Enterprises (SMEs) to Contribute to Nigerian Development" Ghana Journal of Development Studies. Journal of the Faculty of Integrated Development Studies. University for Development Studies, Ghana, Vol.4, No.2. December.Pp. $11-32$

Goldman, H.H. (2005), "The origins and development of quality initiative in American business", The Total Quality Management Magazine, Vol. 17 No. 3, pp. 217-25.

Hasin, M.A.A., Seeluangsawat, R. and Shareef, M.A. (2001), "Statistical measures of customer satisfaction for health care quality assurance: a case study", International Journal of Health Care Quality Assurance, Vol. 14 No. 1, pp. 6-13.

Hua, H., Chin, K. S., Sun, H., \& Xu, Y. (2000). An empirical study on quality management practices in Sanghai manufacturing industries, Total Quality Management, 11(8), 1111-1122.

Ikpefan, O.A., Owolabi, F., Agwu M.E. \& Adetula, D. (2014) Working Capital Management And Profitability Of The Manufacturing Sector: An Empirical Investigation Of Nestle Nigeria Plc and Cadbury Nigeria Plc. European Journal of Business and Social Sciences (EJBSS); Volume 3, Issue 06, pp 23-34 September 2014. Available at: http://www.ejbss.com

Ishikawa, K. (1985), what is Total Quality Control? Prentice-Hall, Eaglewood Cliffs, NJ, pp. 44. Ingram, B.L. and Chung, R.S. (1997), "Client satisfaction data and improvement planning in management mental health care organization", Health Care Management Review, Vol. 22 No. 3, pp. 40-52.

Isiavwe, M.E, Ogunnaike, O.O and Kolawole, H. (2006). "Economic Perspective of Globalization in Nigeria". Journal of Research and Development. Vol. 7(4). Pp 42-53 (NARD, Benue State University, Nigeria)

Sit, W.Y., Ooi, K. B., Lin, B. \& Chong, A.Y.L. (2009), “TQM and customer satisfaction in Malaysia's service sector”,Industrial Management \& Data Systems, 109(7): pp. 957-975.

Sureshchandar, G.S., Chandrasekharan, R., Anantharaman, R.N. and Kamalanabhan, T.J. (2002),"Management's Perception of Total Quality Service in the banking sector of developing economy- a critical analysis", International Journal of Bank Marketing, 20(4): Pp. 181-96

Talib, F., Rahman, Z. \&Qureshi, M.N. (2012), “Impact of Total Quality Management and Service Quality in the Banking Sector”, Journal of Telecommunication System Management, 1: pp.102.

Therese A.J.(2007),"Total quality management and performance The role of organization support and co-worker support”, International Journal of Quality \& Reliability Management,24(6): pp. 617-627.

Vanniarajan, T. (2007), "Internal Service Quality and Performance Outcomes in Commercial Banks", Global Management Review, 1(2):pp. 22-31. 